\title{
Postpneumonectomy pulmonary oedema
}

\author{
L VERHEIJEN-BREEMHAAR, J M BOGAARD, B VAN DEN BERG, C HILVERING
}

From the Department of Pulmonary Diseases and Intensive Care Unit, University Hospital Dijkzigt, Rotterdam, The Netherlands

ABSTRACT The occurrence of pulmonary oedema was studied retrospectively in 243 patients who underwent pneumonectomy in one hospital from 1975 to 1984. Pulmonary oedema developed in eight of 113 patients who had a right sided pneumonectomy and in three of 130 patients undergoing a left sided procedure. It occurred more commonly in patients requiring a second thoracotomy because of blood loss (in three out of seven patients). There were no significant differences preoperatively in pulmonary function, lung perfusion scans, or cardiovascular condition between patients who subsequently developed pulmonary oedema and those who did not. Postoperative fluid balance was significantly more positive in patients developing pulmonary oedema than in those not developing oedema. Thus pulmonary oedema was associated with right sided pneumonectomy, repeat thoracotomy, and more positive fluid balance.

Pulmonary oedema after pneumonectomy is a life threatening condition, usually leading to death. Only a few reports have been published. ${ }^{1-5}$ The largest group of cases, which included two of our patients, ${ }^{2}$ was published by Zeldin et al. ${ }^{5}$ In this report it was suggested that oedema appears to result from infusion of excessive volumes of fluid, leading to increased cardiac output and raised pulmonary artery pressure. Increased pulmonary capillary pressure, ${ }^{3}$ shearing forces produced by increased linear flow velocities, ${ }^{67}$ and possibly increased permeability ${ }^{8}$ may cause an increase of net fluid filtration beyond the limited lymphatic capacity of the remaining lung. To investigate the occurrence of pulmonary oedema after pneumonectomy the records of all patients who underwent pneumonectomy in our hospital during the period 1975-84 were studied retrospectively. The aim of the investigation was to assess any possible relationship beween pulmonary oedema and preoperative pulmonary function, lung perfusion scan, cardiovascular condition, side of operation, and perioperative fluid balance.

\section{Patients and methods}

We reviewed 243 patients. The diagnosis of post-

Address for reprint requests: Dr J M Bogaard, Department of Pulmonary Diseases, University Hospital Dijkzigt, 3015 GD Rotterdam, The Netherlands.

Accepted 7 January 1988 pneumonectomy pulmonary oedema was based on clinical and radiographic evidence - that is, signs of respiratory distress and diffuse pulmonary infiltrates, interstitial at first and alveolar at a later stage. No evidence was present of infection, aspiration, cardiac failure due to arrhythmias or myocardial infarction, thromboembolism, or adult respiratory distress syndrome in the course of septicaemia or other known causes.

The following measurements and tests were performed: preoperative inspiratory vital capacity (VC), forced expiratory volume in one second $\left(\mathrm{FEV}_{1}\right)$, total lung capacity (TLC), functional residual capacity (FRC), and residual volume (RV) were estimated by spirography (Lode D53R spirometer and the helium closed circuit washin method). Data are expressed as percentages of predicted values. ${ }^{10}$

Lung perfusion scintigraphy was performed with technetium- $99 \mathrm{~m}$ labelled albumin microaggregates and the distribution of perfusion to left and right lungs was calculated.

The patient's cardiovascular condition was assessed by noting the presence or absence of signs of ischaemic heart disease, dysrhythmia, and hypertension.

The net fluid balance was calculated for the first 24 hours after the patient had entered the operating theatre by recording total fluid input (blood, blood products, crystalloids) and output (urine production, blood loss, and gastric drainage).

The significance of differences between group means was estimated by Student's $t$ test for differences between groups of unequal size. The $\chi^{2}$ test was used to 
compare the incidence of oedema with respect to the side of operation. ${ }^{\prime \prime}$

\section{Results}

One hundred and thirteen patients underwent right pneumonectomy and 130 had a left sided procedure. Oedema occurred in eight of 113 patients who had had right pneumonectomy and three of the 130 who had had a left sided procedure. In seven cases the diagnosis was made at the time and in the remaining four cases it was made retrospectively.

Preoperative pulmonary function did not differ significantly between patients with and without oedema (table). The amount of functioning lung tissue removed, as calculated from the lung perfusion scans, also showed no significant differences between the right and left pneumonectomy groups

The cardiovascular condition of most patients was normal. No significant differences were present with respect to cardiovascular condition, either between the oedema and the non-oedema groups or between the patients who had had right and left sided pneumonectomy.

Accurate fluid balances were available for all 11 patients who developed pulmonary oedema and in 181 of the remaining 232 patients (figure). Postoperative fluid balance in the 11 patients with oedema was significantly more positive than fluid balance in the groups without oedema ( $p<0.01$ and $p<0.001$ for patients with right and left sided pneumonectomy respectively). Fluid balance was more positive after left sided than after right sided pneumonectomy (fig), although the significance of this difference is marginal $(\mathrm{p}<0.03)$.

Surgery was performed without complication in most patients, although repeat thoracotomy was

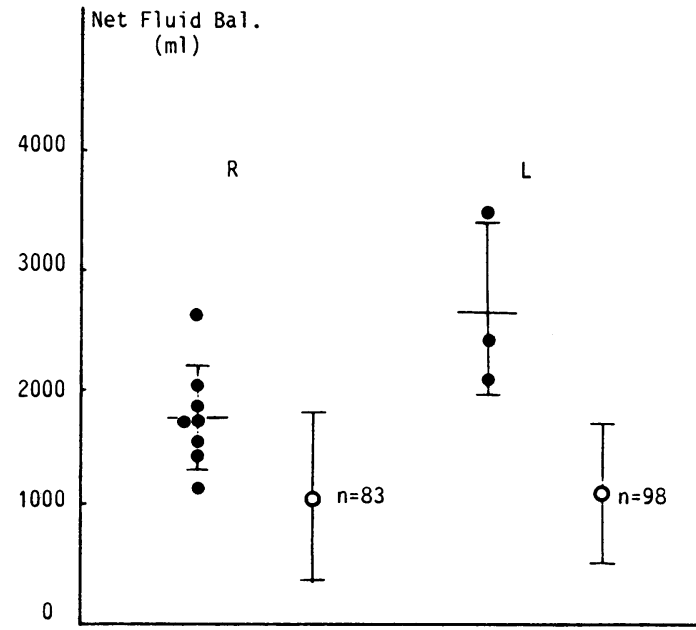

Net fluid balance in the first 24 hours after operation for the patients with (O) and without (O) pulmonary oedema after right and left pneumonectomy: means and 1 SD, with individual data for the patients who developed pulmonary oedema.

necessary because of persistent blood loss in three patients with oedema and in four patients without ( $p$ $<0.005$ ). In all cases repeat operation took place within 24 hours of pneumonectomy.

Postpneumonectomy pulmonary oedema became evident one to seven days after operation. In six patients assisted ventilation with positive end expiratory pressure and a high oxygen $\left(\mathrm{FiO}_{2}>0.40\right)$ inspiratory gas mixture was necessary. The other five patients were given oxygen by a Venturi mask. In five patients Swan-Ganz catheters were inserted when oedema was recognised. Pulmonary artery pressure was raised in two patients $\left(8 \cdot 3 / 2 \cdot 8\right.$ and $\left.7 \cdot 2 / 3 \cdot 2 \mathrm{kPa}^{*}\right)$, ${ }^{*} 1 \mathrm{kPa}=7.5 \mathrm{~mm} \mathrm{Hg}$.

Anthropometric, spirometric and perfusion data in the 243 patients and numbers with cardiovascular disease (means with standard deviations in parentheses for variables)

\begin{tabular}{|c|c|c|c|c|c|c|c|c|c|c|c|c|}
\hline & \multirow{2}{*}{$\begin{array}{l}\text { No of } \\
\text { patients }\end{array}$} & \multirow[b]{2}{*}{$M: F$} & \multirow{2}{*}{$\begin{array}{l}\text { Age } \\
(y)\end{array}$} & \multirow{2}{*}{$\begin{array}{l}\text { Height } \\
(\mathrm{cm})\end{array}$} & \multirow{2}{*}{$\begin{array}{l}\text { Weight } \\
\text { (kg) }\end{array}$} & \multicolumn{5}{|c|}{ Lung volumes } & \multirow{2}{*}{$\begin{array}{l}\text { Lung } \\
\text { perfusion } \\
\text { scan } \\
(\% R)\end{array}$} & \multirow{2}{*}{$\begin{array}{l}\text { Cardiovas } \\
\text { disease } \\
\text { (number) }\end{array}$} \\
\hline & & & & & & $V C^{*}$ & $F E V_{1}^{*}$ & $T L C^{*}$ & $F R C^{*}$ & $R V^{*}$ & & \\
\hline \multicolumn{13}{|c|}{ RIGHT PNEUMONECTOMY } \\
\hline \multicolumn{13}{|c|}{ Pulmonary oedema: } \\
\hline Absent & 105 & $101: 4$ & $\begin{array}{l}60 \cdot 6 \\
(9 \cdot 6)\end{array}$ & $\begin{array}{r}174 \cdot 8 \\
(9 \cdot 6)\end{array}$ & $\begin{array}{l}72 \cdot 8 \\
(7 \cdot 0)\end{array}$ & $\begin{array}{l}93 \\
(14)\end{array}$ & $\begin{array}{c}74 \\
(16)\end{array}$ & $\begin{array}{l}96 \\
(16)\end{array}$ & $\begin{array}{l}108 \\
(26)\end{array}$ & $\begin{array}{l}108 \\
(26)\end{array}$ & $\begin{array}{c}42 \cdot 1 \\
(12 \cdot 4)\end{array}$ & 17 \\
\hline Present & 8 & $6: 2$ & $\begin{array}{l}60.4 \\
(9.9)\end{array}$ & $\begin{array}{l}167.9 \\
-(6.5)\end{array}$ & $\begin{array}{c}63.0 \\
(12.7)\end{array}$ & $\begin{array}{c}96 \\
(17)\end{array}$ & $\begin{array}{c}86 \\
(19)\end{array}$ & $\begin{array}{c}92 \\
(12)\end{array}$ & $\begin{array}{c}97 \\
(14)\end{array}$ & $\begin{array}{l}107 \\
(17)\end{array}$ & $\begin{array}{l}47.0 \\
(5 \cdot 4)\end{array}$ & 3 \\
\hline \multicolumn{13}{|c|}{$\begin{array}{l}\text { LEFT PNEUMONECTOMY } \\
\text { Pulmonary oedema: }\end{array}$} \\
\hline Absent & 127 & & $\begin{array}{l}60 \cdot 6 \\
(9 \cdot 0)\end{array}$ & $\begin{array}{r}174 \cdot 4 \\
(6 \cdot 5)\end{array}$ & $\begin{array}{c}74 \cdot 2 \\
(10 \cdot 0)\end{array}$ & $\begin{array}{l}95 \\
(15)\end{array}$ & $\begin{array}{l}75 \\
(16)\end{array}$ & $\begin{array}{l}96 \\
(14)\end{array}$ & $\begin{array}{l}105 \\
(21)\end{array}$ & $\begin{array}{l}105 \\
(24)\end{array}$ & $\begin{array}{l}62 \cdot 2 \\
(11 \cdot 1)\end{array}$ & \\
\hline Present & 3 & $3: 0$ & $\begin{array}{c}48.7 \\
(13.4)\end{array}$ & $\begin{array}{r}184 \cdot 3 \\
(4 \cdot 0)\end{array}$ & $\begin{array}{l}88.7 \\
(5 \cdot 0)\end{array}$ & $\begin{array}{c}93 \\
(17)\end{array}$ & $\begin{array}{l}90 \\
(10)\end{array}$ & $\begin{array}{l}99 \\
(9)\end{array}$ & $\begin{array}{l}112 \\
(25)\end{array}$ & $\begin{array}{l}103 \\
\text { (1) }\end{array}$ & $\begin{array}{c}61 \\
(13.4)\end{array}$ & 1 \\
\hline
\end{tabular}


systolic/diastolic pressures whereas in three other patients pulmonary hypertension was borderline $(5 \cdot 3 /$ $2 \cdot 1,4 \cdot 5 / 2 \cdot 0,4 \cdot 7 / 1 \cdot 7 \mathrm{kPa})$. Two patients showed normal wedge pressures; in the other three no wedge pressure was obtained. Nine patients were given a diuretic (frusemide) when oedema developed, but without immediate improvement. Three of the six patients requiring assisted ventilation died, 6-11 days after surgery.

\section{Discussion}

It has been suggested that after pneumonectomy the remaining lung is abnormally susceptible to the development of pulmonary oedema. ${ }^{1812}$ Fortunately this is a rare complication. In our patients the frequency was $4 \%$.

In general, one or both of two mechanisms contribute to the development of pulmonary oedemanamely, an increase in capillary hydrostatic pressure ("high pressure oedema") and an increase in vascular permeability ("permeability oedema"). With normal endothelial integrity the lung is relatively resistant to the formation of oedema. One of the safety mechanisms is the lymphatic pump, which increases its pumping rate as the filtration rate rises. ${ }^{13}$ Lymph flow rates 5-10 times the baseline rate are possible. ${ }^{14}$ When one lung is removed, a proportional reduction of lymphatic pump capacity would be expected, with a loss of about $55 \%$ after removal of the right lung. The perfusion scan data (table) did not, however, suggest that a greater amount of functioning lung tissue had been removed in patients who developed oedema, so a reduction in lymphatic pump capacity alone seems unlikely to be responsible for the development of pulmonary oedema. Nor was their any difference in the degree of impairment of pulmonary function between the groups.

Animal studies have shown that the lung tissue remaining after pneumonectomy is more susceptible to the accumulation of extravascular fluid after a haemodynamic challenge than are normal lungs. ${ }^{512}$ The patients with oedema did not show any more evidence of cardiovascular problems than the other patients and, although haemodynamic measurements by Swan-Ganz catheter were not obtained in all the affected patients, the normal wedge pressures in two patients with pulmonary oedema suggest that left ventricular failure was not a contributory factor. Falsely low values may, however, be obtained after pneumonectomy because of lowering of cardiac output from a reduction of the remaining cross sectional area of the pulmonary circulation by the balloon of the Swan-Ganz catheter. ${ }^{4}$ In two of our patients pulmonary artery pressure was raised, as reported in another study $^{3}$ and in animal studies. ${ }^{5}$ This might be due to an increased blood flow to the remaining lung, moving the mean capillary pressure point towards the venous side of the capillary and thus increasing the net filtration force.$^{35}$ In this way high flow after pneumonectomy could increase the hydrostatic filtering force beyond the limited lymphatic pump capacity of the remaining lung.

Haemodynamic factors interact in an important way with endothelial barrier injury. ${ }^{\text {is }}$ Local stress on endothelial surfaces, at critical points in the circulation, may lead to rapid and severe changes in permeability. ${ }^{16} \mathrm{An}$ increase in blood flow in the remaining lung could cause an increase in tangential and shearing forces in the pulmonary microcirculation, resulting in damage to capillary walls and leakage of fluid into the interstitium and the alveoli. ${ }^{67}$

Animal studies have shown that pulmonary oedema fluid accumulating after removal of $70 \%$ of pulmonary tissue has a high protein content, consistent with increased vascular permeability rather than passive transudation alone.

The differences in perioperative fluid balances between our patients with oedema and those without oedema were significant and indicate an important role of overperfusion in the development of oedema. It is not, however, clear whether the oedema results from an increase in mean capillary pressure or from increased permeability of the endothelium or from both.

In the patients with oedema significantly more second thoracotomies had been performed (three of 11 compared with four of 232). Postoperative bleeding may have increased the risk for positive fluid balance by overperfusion. Although accurate data about fluid balance were obtained only in the first 24 hours after operation and oedema developed at a later stage (one to seven days after operation), hyperperfusion appears likely to be an important factor in postpneumonectomy pulmonary oedema. Other risk factors include a right pneumonectomy and repeat thoracotomy.

We gratefully acknowledge the assistance of $\mathrm{Mr} \mathbf{C ~ J}$ Jongkind in the data analysis and the secretarial support of Mrs J M van Rijn-Engelfriet.

\section{References}

1 Hutchin P, Terzi RG, Hollandsworth LA, Johnson G Jr, Peters RM. Pulmonary congestion following infusion of large fluid loads in thoracic surgical patients. Ann Thorac Surg 1969;8:339-47.

2 Berg B van den, Hilvering C. Postpneumonectomy pulmonary edema: a case report. In: Prakash $\mathrm{O}$, ed. Applied physiology in clinical respiratory care. The Hague: Martinus Nijhoff, 1982:465-72.

3 Peters RM. Postpneumonectomy pulmonary edema. In: 
Prakash O, ed. Applied physiology in clinical respiratory care. The Hague: Martinus Nijhoff, 1982:111-24.

4 Wittnich C, Trudel J, Zidulka A, Chu-Jeng Chiu R. Misleading "pulmonary wedge pressure" after pneumonectomy: its importance in postoperative fluid therapy. Ann Thorac Surg 1986;42:192-6.

5 Zeldin RA, Normandin D, Landtwing D, Peters RM. Postpneumonectomy pulmonary edema. J Thorac Cardiovasc Surg 1984;87:359-65.

6 Staub NC. Pulmonary edema due to increased microvascular permeability to fluid and protein. Circ Res 1978; 43:143-51

7 Ohkuda K, Nakahara K, Weidner WJ, Binder A, Staub NC. Lung fluid exchange after uneven pulmonary artery obstruction in sheep. Circ Res 1978;43:152-61.

8 Gibbon JH, Gibbon MH. Experimental pulmonary edema following lobectomy and plasma infusions. Surgery 1942;12:694-704.

9 Ostendorf P, Birzle H, Vogel W, Mittermayer C. Pulmonary radiographic abnormalities in shock. Radiology
1975;115:257-63.

10 Quanjer PhH. Standardized lung function testing. Bullo Eur Physiopathol Respir 1983;19 (suppl 5).

11 Snedecor GW, Cochran WG. Statistical methods. Iowa:등 Iowa State University Press, 1973.

12 Little AG, Langmuir VK, Singer AH, Skinner DB. Hemodynamic pulmonary edema in dog lungs after contralateral pneumonectomy and mediastinal lym- $\infty$ phatic interruption. Lung 1984;162:139-45.

13 Taylor AE, Grimbert F, Rutili G, Kvietys PR, Parker JC. Pulmonary edema: changes in Starling forces and $\vec{\omega}$ lymph flow. In: Hargens AR, ed. Tissue fluid pressure and composition. Baltimore: Williams and Williams, $\vec{x}$ 1981:135-43.

14 Staub NC. Pulmonary edema, physiologic approaches to management. Chest 1978;74:559-64.

15 Staub NC. The hemodynamics of pulmonary edema. BullN Eur Physiopathol Respir 1986;22:319-22.

16 Staub NC. Pulmonary edema due to increased microvas- 음 cular permeability. Ann Rev Med 1981;32:291-312. 